\title{
WOMEN ECONOMISTS IN THE 1890s: JOURNALS, BOOKS AND THE OLD PALGRAVE
}

\author{
BY \\ ROBERT W. DIMAND
}

\section{INTRODUCTION}

Just over a century ago two noteworthy books in economics were published by women, contrary to the widespread modern impression that women's participation in economics is a recent phenomenon. Charlotte Perkins Gilman published Women and Economics (1898a, cf. Gilman 1898b), a landmark work of feminist and institutionalist economics (see M. A. Dimand 1995b). Rosa Luxemburg published The Industrial Development of Poland (1898) based on her 1897 Zurich doctoral dissertation. This distinguished contribution showed promise of the great abilities displayed in her magnum opus, The Accumulation of Capital (1913), a study that deserves recognition for its importance in macrodynamics and the theory of economic growth as well as in Marxian economics (see Joan Robinson's introduction to the 1951 translation). These two authors stand as giants in the history of economics - or would do so, if historians of economics were paying attention-but they were very far from being the only women contributing to economics in the 1890 s.

Textbooks on the history of economic thought generally leave the impression that very few women contributed to economics until very recently (see $R$. Dimand 1995). In his Digression: On Earlier Writings by Women, William Baumol (1985, p. 11) discovered "that before World War I, as today, a (distressingly) few women were contributing to the literature" and listed seven journal articles by women, two from during World War I, one from 1923, and four from before the war, the earliest being Clementina Black (1904). This picture has been challenged, notably in a University of Sydney working paper by Peter Groenewegen and Susan King (1994), who counted women's articles in five leading economics journals from 1900 to 1940, and in a series of papers by Barbara Libby and by Evelyn Forget on women in the U.S. economics profession 1900-1940 (see Dimand, Dimand, and Forget 1995 for references).

However, these studies have not covered the 1890s. For three of the journals used in the Groenewegen and King study, the Quarterly Journal of Economics (founded 1886), the Economic Journal (founded 1891), and the Journal of

Department of Economics, Brock University, St. Catharines, Ontario L2S 3A1. 
Political Economy (founded 1892), I have counted 44 articles by 30 women in the 1890s, which are listed in the references to this paper. (The other two journals used by Groenewegen and King did not yet exist in the 1890s: the American Economic Review began with Katharine Coman (1911a) as its lead article, while the first volume of Economica in 1925 carried two articles by Margaret Hope Hogg and one by Margaret S. Miller.) Of these 44 articles, the only ones co-authored with a man were two that Beatrice Webb wrote with Sidney Webb. Another finding of this paper is that women were a higher proportion of the contributors to Palgrave's Dictionary of Political Economy (1894-99/1910) than of the contributors to The New Palgrave (Eatwell, Milgate, and Newman, 1987). Women were also active in economics on the periphery of the English-speaking academic world in the 1890s, notably in The Australian Economist.

This paper surveys women's contributions to economics in English in the 1890 s, seeking an overview of who these women economists were, what they published, and, where known, what they contributed subsequently, with some comparison to contributions of women to later journals and reference works. The paper is a by-product of research for a Biographical Dictionary of Women Economists (Dimand, Dimand, and Forget, in preparation). Only publications in English are surveyed here, but the coverage of the Biographical Dictionary will be wider (see the section "Some Continental European Women Economists After Luxemburg" in Dimand 1998, and the three entries by Aiko Ikeo on early Japanese women economists in Dimand, Dimand, and Forget, in preparation).

This body of work is intended to be provocative, not definitive, and the hope is that readers will conclude that this field has interesting stories still to be told, and will be moved to undertake research.

\section{THE WOMEN ECONOMISTS OF PALGRAVE'S DICTIONARY}

The great Dictionary of Political Economy edited by R. H. Inglis Palgrave, successor to Walter Bagehot as editor of The Economist, attained such stature that when a new multi-volume, encyclopaedic survey of economics was undertaken nine decades later, it was named The New Palgrave: A Dictionary of Economics. Palgrave's Dictionary (1894-99/1910), together with the listing in the bibliography below of journal articles in English by women economists in the 1890 s, provides an opportunity to examine the contributions to economics made by English-speaking women in that decade and to see what the economics profession had to say in the $1890 \mathrm{~s}$ about the economic role of women. The New Palgrave (Eatwell, Milgate, and Newman 1987) offers a standard of comparison, showing the extent to which things have changed. The belief that women did not participate in the discipline of economics in the 1890s turns out to be erroneous. Palgrave's Dictionary was not the first major work of reference to include contributions by women economists. The ninth edition of the Encyclopaedia Britannica had included Clementina Black (of the Women's Industrial Council, later an Economic Journal contributor in 1904 and 1906) on Harriet Martineau, and Millicent Garrett Fawcett on, or rather against, "Communism" (balancing Thomas Kirkup's enthusiastic article on "Socialism"). 
Including the edition edited by Henry Higgs in 1925-27, Palgrave's Dictionary had 249 contributors. They differed greatly in the number of articles they wrote, from Professor Alfred Marshall's single entry, on the teaching of economics at Cambridge, to a remarkable 131 articles by Francis Ysidro Edgeworth, Drummond Professor of Political Economy at Oxford (sixteen of which were reprinted in The New Palgrave). John Neville Keynes contributed seventeen entries, and many other famous names appear, including John Bates Clark, Richard Ely, Charles Gide, Frank Taussig, Frederick Maitland and Sir Frederick Pollock, Phillip Wicksteed and Friedrich von Wieser, and an accountant named Paul Waterhouse. Many of the contributors are listed only with initials, last name, and no affiliation, and where these individuals are otherwise unknown to me, so is their gender. Twelve of the 249 contributors are certainly women, a proportion of 4.8 percent, and a higher proportion than that of the contributors to The New Palgrave (44 out of 966 , or 4.55 percent, plus any who appeared with initials instead of first names and who I did not happen to recognize as female). These twelve women wrote 197 dictionary entries. In addition, F. M. Butlin, who wrote on "Transportation, economic effects of" (that is, deportation to Australia or Siberia), appears in the American Economic Association Index of Economic Journals only for an Economic Journal piece on the International Congress of Women (Butlin 1899). The National Union Catalogue lists Among the Danes by F. M. Butlin in 1909, and Le Français per les images by Frances Marianne Butlin in 1931. If this is the same person, Palgrave's Dictionary had 5.2 per cent of women among its contributors.

Who were the women who published in Palgrave's Dictionary? While the male contributors to the third volume alone included many American and French economists, and contributors from Austria, Belgium, Italy, Germany, Hungary, Western Australia, and even Toronto and Lennoxville (Quebec), the female contributors appear to have all been British. Some went on to distinguished careers, while others, failing to find jobs in economics, were lost to the discipline. Clara Elizabeth Collet wrote on "Female labour," as well as on "Females and children, earnings of" and on Maria Edgeworth, adding articles on Charles Booth and David Schloss in the 1925 edition. The only person to publish in both the first and the fiftieth volume of the Economic Journal, Collet also published in the Quarterly Journal of Economics (Collet 1891a) and in the Journal of the Royal Statistical Society from its $61^{\text {st }}$ volume in 1898 to its $108^{\text {th }}$ volume in 1945. Continuing the interests of her Palgrave entries, Collet wrote JRSS articles on "The present position of women in industry" in 1942 and on "Charles Booth, the Denison Club, and H. Llewellyn Smith" in 1945. In 1889 and 1891, Collet contributed chapters on women's work to Charles Booth's Life and Labour of the People in London (1902/1970).

Collet had a long and distinguished career in public service (notably at the Board of Trade) and served on the councils of the Royal Economic Society (from 1918 to 1941) and Royal Statistical Society (from 1919 to 1935) (see Groenewegen 1994, pp. 147-73, cf. Marshall 1902). As a child, Collet had been close to the Marx family - as was Clementina Black. Her Palgrave articles on "Female labour" and "Female earnings" were extended in the 1925-27 edition by Dora M. Barton, who had published JRSS articles on women's wages in 1919 
(with a comment by Collet) and 1921. The Palgrave article on "Women's wages," however, was written by William Smart of the University of Glasgow, whose paper on women's wages presented to the Philosophical Society of Glasgow in 1892 is discussed favourably by Michèle Pujol (1992, pp. 61-67), without mention of Smart's Palgrave entry.

Edith M. Deverell, a research student at the London School of Economics, wrote the Palgrave entry on "Trunk acts," and published twice in the Economic Journal on types of workers benefit clubs (Deverell 1898, 1899). Ethel R. Faraday, MA, wrote on Thomas Paine, "Productive and unproductive labour," "Produit net," and "Restrictions on labour." She does not appear in the AEA Index of Economic Journals, but in 1933 E. R. Faraday and L. W. Faraday of the Girls' Intermediate School, Treforest, published a book of Form-Room Plays for Girls.

Caroline A. Foley wrote seventeen Palgrave entries, including "Rent of ability," "Science, Economic, as distinguished from art," "Statics, Social, and social dynamics," as well as twelve biographical entries. Her entry, "Fashion, economic influence of," was related to her 1893 Economic Journal article, "Fashion," and reflects an unusual economic interest (see Fullbrook 1998). She also translated from the German Carl Menger's "On the Origin of Money" for the Economic Journal (Menger 1892) and three Economic Journal contributions by Gustav Cohn, two in 1894 and the other in 1899 , as well as translating from Italian for the Economic Journal two articles by Francesco Nitti in 1893, one by Ugo Rabbeno in 1894, and one by Achille Loria in 1900.

As Caroline Augusta Foley Rhys David, she went on to an eminent career, filling nearly three columns of the British Museum catalogue with her books, but not in economics; she achieved success as a translator and author of works on Buddhism. Her only later economic publication was the chapter "Economic Conditions according to Early Buddhist Literature" in the Cambridge History of India. "The most eminent of woman Orientalists" (Jayawardena 1995, p. 159), Rhys David took a philosophy degree at University College, London, and in 1894 she married the Pali scholar who wrote the Palgrave entry on "Caste." From 1900 she was active in the Pali Text Society, becoming its secretary in 1907. Kumari Jayawardena (1995, pp. 159-61) reports that:

She taught Indian philosophy at the University of Manchester from 1910 to 1913, and from 1918 to 1933 was lecturer in the History of Buddhism at the School of Oriental Studies in London. After her husband's death in 1922 she succeeded him as president of the Pali Text Society. Caroline Rhys David was also a committed feminist. From 1890 to 1894 she worked in societies concerned with the welfare of working women and children, and from 1896 to 1914 was active in women's suffrage movement. The Buddhist Society, under her influence, spoke out for women's rights... She was a typical "new woman" of the period, moving in feminist circles, involving herself in women's struggles, doing academic work, raising three children, and writing about Buddhism up to her death in 1942 ... the feminist analysis that Rhys David brought to her Pali scholarship gave fresh meanings to the old texts and made known the "new women" of the past to audiences in the East and West."

Perhaps her departure from economics to Pali scholarship was an unavoidable 
result of her marriage, but it was clearly a loss to scholarship in economics. How many economists in the 1890s thought of analyzing the economics of fashion? (Similarly, Emily Fogg Meade's 1901 Journal of Political Economy article on the economics of advertising was ahead of its time in choice of topic.)

Lettice Ilbert of Somerville College, Oxford, eldest daughter of the Clerk of the House of Commons, wrote on old age pensions for Palgrave's Dictionary. As Lettice Fisher (married to H. A. L. Fisher, historian and Liberal education minister), she published in the Economic Journal about urban housing problems in 1899, 1902, and 1905. E. Dixon of Girton College, Cambridge, contributed seven biographical entries and published on "Craftswomen in the Livre des métiers" in the Economic Journal (Dixon 1895).

Alice Law, also of Girton, contributed fifty-eight articles, mostly biographical, the rest historical-apart from one on "Residual and waste products (by-products)" and another on "Industrial education in England." Her subsequent publications were as a poet and a writer on the Brontë sisters and their novels. Eleanor G. Powell of Somerville contributed even more with eighty-two biographical and historical articles, one of which (on Thomas Gresham) was reprinted in The New Palgrave. She does not appear in the AEA Index of Economic Journals or the British Museum Catalogue of Printed Books, nor does Mary Trice Martin, whose seven entries were on historical topics such as medieval forests, sumptuary laws, knight's service, and the Staple-although they may have published in historical journals.

Twelve biographical and historical entries on topics such as the South Sea bubble and the Russia Company were written by Ellen McArthur, tutor and Head Lecturer in History at Girton. McArthur also served as lecturer in economic history for extension classes at Cambridge, and occasional lecturer in economic history at the London School of Economics. Of all the women who published in Palgrave's Dictionary of Political Economy, only Ellen McArthur had an academic career in economics or economic history. However, had she wished, Beatrice Webb could no doubt have had such a position at LSE, which she co-founded.

Cambridge did not confer degrees on women until 1923 (nor did Oxford until 1920), so, late in her career, McArthur became the first of the Cambridge women to be awarded a Litt. D. by Trinity College, Dublin (Berg 1992, p. 317). McArthur wrote with Archdeacon William Cunningham, chairman of the council of Girton College, on Outlines of English Industrial History (Cunningham and McArthur 1895), which went through four editions. When McArthur was appointed the first woman extension lecturer, Alfred Marshall, chairman of the Extension Syndicate, went to the vice-chancellor, trying to get her appointment quashed on the grounds that lecturing to largely male audiences would damage a woman's character-although he had not minded Mary Paley Marshall lecturing to mixed audiences at University College, Bristol, when he was principal there (Berg 1992, p. 315). Cunningham's mentoring of female economic historians at Girton was yet one more occasion for clashes between him and Marshall.

Another Girton historian and Trinity College, Dublin, Litt. D. (followed belatedly by an M. A. and LL. M. from Cambridge), Lillian Knowles, became 
professor of economic history at LSE and was Dean of the Faculty of Economics of the University of London when she died in 1926. Although Knowles primarily published through books (Knowles 1921, 1924, 1932), she wrote three Economic Journal articles (including Cunningham's obituary) in three consecutive issues in 1919. The London School of Economics and Political Science was then a leader in academic employment of women, with 43 women among the 200 people who held full-time teaching posts at LSE from its foundation in 1895 until 1932; in 1990 there were only 53 women among 308 full-time teaching staff (Berg 1992, p. 318).

There were no Palgrave contributors from Newnham College, Cambridge, where Mary Paley Marshall was director of studies in economics, perhaps reflecting Alfred Marshall's distance from Palgrave's project. Alfred Marshall's unsuccessful rival for control of economics teaching at Cambridge, the economic historian William Cunningham, may well have been instrumental in bringing Girton women economic historians into Palgrave's Dictionary and the University of London, since Cunningham contributed eight Palgrave articles and was Tooke Professor of Economics at King's College, London, from 1891 to 1897 (while remaining chairman of the Girton College council, a Fellow of Trinity College, Cambridge, and vicar of the university church, Great St. Mary's, Cambridge).

The Palgrave entry, "Standard rate (of wages)," was written by Sidney and Beatrice Webb, the founders of LSE, who published an Economic Journal article on that topic (Webb and Webb 1896b). While caring for her father, a former president of the Grand Trunk Railway of Canada, after he suffered a stroke in 1889, Beatrice Potter (as she then was) taught herself political economy, composing essays on "The History of English Economics" and "The Economic Theory of Karl Marx" (Polkinghorn and Thomson 1998, p. 58). Beatrice Webb, who became the first female Fellow of the British Academy in the 1920s, published three Economic Journal articles written jointly with her husband, but "the firm of Webb and Webb" produced most of its research in the form of books. In the 1890s, their major joint publications included eight hundred pages on the History of Trade Unionism (1894, later translated into Russian by Lenin) and nine hundred pages on Industrial Democracy (1897). Beatrice's single-authored work included a volume on the British co-operative movement (Potter 1891) and a Fabian Tract on Women and the Factory Acts (Webb 1896).

Later, their major scholarly study filled eleven volumes on the history of English local government (Webb and Webb 1903-1930/1963), while perhaps their most influential contribution to social thought was the two-volume Minority Report of the Poor Law Commission in 1909, for which the University of Manchester awarded Beatrice Webb an honorary doctorate. Like Clara Collet, Beatrice Potter (later Webb) contributed to Charles Booth's Life and Labour of the People in London (1902/1970). Beatrice Webb's 1919 pamphlet, The Wages of Men and Women: Should They Be Equal?, is cited (along with Fawcett 1918) on occupational segregation and gender pay differentials in Francine Blau's New Palgrave article on gender. From 1906, Beatrice Webb reversed her opposition to feminism and women's suffrage. Thereafter, she advanced a feminist analysis of the labor market in works such as her Minority Report of the War Cabinet Committee on Women in Industry, which Michèle Pujol (1992, pp. 84-83) 
contrasted sharply with Sidney Webb's earlier views on women's wages. For a different view upholding the feminism of the Webbs, see four articles by Chris Nyland $e t$ al., three previously published, collected as chapters 3 to 6 of Beilharz and Nyland (1998).

The active participation of British women economists and economic historians in Palgrave's Dictionary in the 1890 s was comparable to the contribution of American women economists to the Encyclopedia of the Social Sciences in the 1930s. That compendium included seven entries by Edith Abbott, Dean of Social Service Administration at the University of Chicago and author of nineteen Journal of Political Economy articles from 1904 to 1925, and two by her colleague Sophonisba Breckenridge, author of eight of JPE articles beginning in 1901 (two of them with Abbott). Caroline F. Ware, author of The Early New England Cotton Manufacture (1931/1966) and wife of Gardiner Means, contributed six articles. As an economic historian, Ware worked where two disciplines overlapped. After publishing in the Quarterly Journal of Economics (Ware 1926) and working as a research economist for the National Resources Planning Committee, she edited The Cultural Approach to History for the American Historical Association (Ware 1940). Eleven articles were by Dorothy Wolff Douglas, the feminist first wife of the future U.S. Senator, Paul Douglas of the Cobb-Douglas production function (see their prize-winning 1921 joint essay in the American Economic Review, her 1920 Quarterly Journal of Economics article on women's cost of living, and, for her later, more radical work, a 1940 Science and Society article on "Land and Labor in Mexico" and her 1953 book on the Polish and Czech economies).

Blanche Hazard Sprague wrote on the leather industries (the leather, boot, and shoe industries having been the subject of her dissertation in the Harvard Economic Studies series and her 1913 QJE article, both written as Blanche Hazard). Helen Sumner Woodbury, a 1908 Wisconsin Ph. D. who had been a student and collaborator of John R. Commons before going into government (see Sumner 1910), wrote on Governor Altgeld-who pardoned the Haymarket anarchists.

Hazel Kyrk, professor of economics and home economics at the University of Chicago, winner of the Hart, Schaffner and Marx dissertation prize, and in some respects a precursor of Gary Becker in "the new home economics," wrote on home economics (cf. Kyrk 1923, 1933). Among other women who also published in leading economics journals, Ethel B. Dietrich, author of three articles in $A E R$ and one in $J P E$ from 1928 to 1935 , wrote the entry on the textile industry (cf. Dietrich 1928). Dorothy Johnson Orchard, author of a two-part JPE article on agrarian problems in modern Japan (Orchard 1929), wrote about trade unions in the Far and Near East.

\section{OTHER BRITISH WOMEN ECONOMISTS OF THE 1890s}

Some notable Englishwomen published in the Economic Journal in the 1890s but not in Palgrave's Dictionary. Barbara Bradby Hammond (Black and Bradby 1899) became a prominent economic and social historian, writing three books with her husband, J. L. Hammond, on the village labourers, town labourers, and 
skilled labourers from 1760 to 1832 (Hammond and Hammond 1911, 1917, 1919). The pair wrote other books on topics such as the rise of modern industry, as well as contributing single-authored articles to the Economic History supplement of the Economic Journal in 1928 and 1931 (see Rick Kleer in Dimand, Dimand and Forget, in preparation, for full references). The daughter of a headmaster of Haileybury College, Hammond won first-class honours in classics at Lady Margaret Hall, Oxford, where she later became an honorary fellow and, like her husband, received an honorary doctorate from Oxford.

Margaret Bondfield published in the Economic Journal (Bondfield 1899), later published (as did Beatrice Webb) in a volume on social and economic problems from the standpoint of consumers (Bondfield 1928), and from 1929 to 1931 was Minister of Labour in Britain's second Labour government-the first female minister in Britain. Similarly, in the 1940s, the first female cabinet minister in Sweden was an economist, Karin Kock, member of the Stockholm School who published extensively and internationally on interest rates, monetary economics, measurement of national income, and international trade policy (see Dimand, Dimand, and Forget, in preparation, and R. Dimand 1995, p. 8.).

Helen Dendy Bosanquet took a first in the Moral Sciences Tripos while at Newnham, taught briefly as a University Extension lecturer, and was prominent in the Charity Organisation Society, whose history she wrote in 1914. As a member of the Royal Commission on the Poor Laws (1905-1909), she took a liberal stand in favour of voluntary charity and the Charity Organisation Society against the interventionist position of her fellow commissioner Beatrice Webb (see A. M. McBriar, An Edwardian Mixed Doubles: The Bosanquets versus the Webbs, 1987). She published ten articles in the Economic Journal from its first volume in 1891 until 1920, and from 1909 she edited the Charity Organisation Review. The last of her books, a Cobdenite defense of free trade, was published by the Norwegian Nobel Institute in 1924, the year before her death.

Bessie Leigh Hutchins followed her first Economic Journal article (Hutchins 1899-1900) with six more Economic Journal articles and two in the Journal of the Royal Statistical Society until 1921. Most of her articles dealt with women's employment, as did her book on Women in Modern Industry (1915). Her History of Factory Legislation (Hutchins and Harrison 1903) appeared with a preface by Sidney Webb, and was written with a co-author identified as A. Harrison (Mrs. Spencer), B. A., D. Sc. (Econ.), London.

In the 1890s, the Economic Journal also published contributions by Sophie Willock Bryant (1894) on educational finance, Ada Heather-Bigg (1894) on the wife's contribution to family income, Henriette Jastrow (1899), Amelia Sarah Levetus (1897), and Margrieta van der Veen (1898a, 1898b) on women's work in Continental Europe, and Christabel Osborn (1895a, 1895b, 1898) on the United States. Mary Paley Marshall (1896) published on a conference of women workers, Beatrice Hewart (1898) on the wages of London vestry employees, Florence Davenport-Hill (1893) on boarding-out of pauper children, Janice Hogarth (1896) on German social insurance legislation, and Millicent Garrett Fawcett (1892) on women's wages (cf. Fawcett 1918). Fawcett, who became Dame Millicent in 1924 for her leadership of the moderate or constitutional wing of the women's suffrage movement, published volumes on Political Economy 
for Beginners (1870), Tales in Political Economy (1874), and, with her husband Henry Fawcett, Essays and Lectures on Social and Political Subjects (1872). These accomplishments were completed while acting as amanuensis to her blind husband, who was Professor of Political Economy at Cambridge until his death in 1884 (Polkinghorn and Thomson 1998, Chapter 3). Just barely outside the 1890s, in December 1889, Fabian Essays in Socialism included an essay on "Industry Under Socialism" by Annie Besant, who, though remembered for her colourful involvement with Theosophy, was also a serious political figure who rose to the presidency of the Indian National Congress.

\section{AMERICAN WOMEN ECONOMISTS OF THE 1890s}

Charlotte Perkins Gilman's Women and Economics (1898a) was an outstanding feminist analysis of gender as an economic institution, and is a work that should rank with Thorstein Veblen's Theory of the Leisure Class (1899) in the chapter that any textbook of the history of economic thought devotes to institutionalism. Although not formally trained as an economist (just as four of the first five presidents of the American Economic Association had taken at most one course in political economy), Gilman emphasized externalities, inefficient resource allocation when household labour was not explicitly priced, and the economies of scale and gains from specialization that could be achieved by market provision of child-care, cleaning, and cooking (see M. A. Dimand 1995b, Hill 1980). Andrew Sinclair (1965, p. 272) described Gilman as "the greatest writer the feminists ever produced on sociology and economics, the Marx and Veblen of the movement [who] always asked the brutal question and was never satisfied by the easy answer." In 1904, the Journal of Political Economy published Caroline Hill's "The Economic Value of the Home," a twelve-page review article on Gilman (1903), but thereafter the economics profession paid less attention, and the very brief New Palgrave entry on Gilman does little more than list her major works.

One economist who did read Gilman was Theresa Schmid McMahon, whose 1909 University of Wisconsin doctoral dissertation was published as Women and Economic Evolution (1909). McMahon taught economics at the University of Washington from 1910 to 1937, becoming a full professor in 1929, and declined an invitation from her former University of Washington colleague Paul Douglas to join the Economics Department at the University of Chicago (see her autobiography "My Story," published as an appendix to Howe, 1989, pp. 238280; later her student George Stigler did go to Chicago). Like Emily Greene Balch at Wellesley, McMahon created a course on "Women in Industry," which she taught from 1916 to 1931 .

Gilman's mentor and close friend, Helen Campbell, published books on Prisoners of Poverty: Women Wage Workers (1887) and Women Wage-Earners (1893). Richard Ely of the University of Wisconsin contributed a foreword to her 1893 volume, which had won a prize from the American Economic Association (of which Ely was the founding secretary, 1886-92). According to Mary Hill (1980, pp. 239, 245-46), "Having received Ely's blessing, but not a Ph.D., ... [Campbell was] invited to teach at the University of Wisconsin, again 
with Ely's backing .... Well-respected publications notwithstanding, she was not never offered the permanent Wisconsin academic post she apparently hoped for and to some extent expected" (cf. M. A. Dimand 1995a, pp. 45, 54, and John B. Davis on Campbell in Dimand, Dimand, and Forget, in preparation). When, in 1908, Wisconsin did award a Ph.D. to Helen Sumner (later Woodbury), she was encouraged-as were many of Commons' male students-to seek government work rather than an academic position. But Theresa McMahon, who received a Wisconsin $\mathrm{Ph} . \mathrm{D}$. the following year, did have a successful academic career.

Unlike Campbell, Sumner was at least able to remain in economics. Denied a career in economics, Campbell then turned to home economics (Campbell 1896). The career of Helen Campbell provides an example of how remedying the neglect of early women economists can enrich fields of scholarship other than the history of economic thought. In her entertaining and erudite dissection of turn-of-the-century domestic science, Laura Shapiro (1986, pp. 86, 132, 134, $168,172-74,189-90,212)$ has much to say about Helen Campbell as a home economist who deplored and wished to reform the way the poor cooked. However, the picture of Campbell that emerges from Shapiro (1986) is a caricature, thrown out of balance by failure to mention economics, Gilman, or Campbell's books on women wage-earners and the causes and possible remedies for their poverty.

In 1900, Katherine Bement Davis became the first woman to receive a Ph.D. in economics from the University of Chicago (Edith Abbott was the second in 1905, Sophonisba Breckenridge's $1901 \mathrm{Ph}$. D. being in political science and economics), and the fourth from any American university. From 1898 to 1900 , she published four articles in the Journal of Political Economy, two based on her dissertation. After graduation, she left economics to become superintendent of the newly opened New York Reformatory for Women from 1900 until the time she became New York City's Commissioner of Corrections in 1913. Then, in 1916 she became chairman of the newly established Parole Commission. Her work from 1918 to 1928 as general secretary of the Rockefeller-supported Bureau of Social Hygiene led to her book on Factors in the Sex Life of Twenty-Two Hundred Women (1929). In 1922, the National League of Women Workers hailed Davis as one of the twelve greatest living American women (see Claire Holton Hammond on Davis, on Abbott, and on Breckenridge, in Dimand, Dimand, and Forget, in preparation).

Edith Abbott and Sophonisba Breckenridge taught at the Chicago School of Civics and Philanthropy, re-entering a university when that school became the University of Chicago's Graduate School of Social Service Administration. They continued to publish in the Journal of Political Economy until they founded the Social Service Review in 1927 (Clara Collet contributed to the first volume). Breckenridge became an economist after failing to attract clients as a lawyer (called to the Kentucky Bar in 1895, University of Chicago JD 1904). In contrast, Sadie Tanner Mossell Alexander, the first black woman in the United States to receive a Ph.D. (in economics at the University of Pennsylvania in 1921), became a prominent lawyer after failing to find employment as 
an economist. She served as chair of the White House Conference on Aging in the late 1970s and for twenty-five years as Secretary of the National Urban League (Malveaux 1991).

In 1895 in the Journal of Political Economy, one of J. Laurence Laughlin's graduate students at the University of Chicago questioned the quantity theory of money on the grounds that the observed behaviour of the U.S. price level was not consistent with changes in the money supply. The article was signed $\mathrm{S}$. McLean Hardy; the S. stood for Sara. From 1895 to 1905, Helen Bliss, writing as H. L. Bliss, published six articles on census statistics in the Journal of Political Economy, which also published a substantial review article by Katharine Felton (1898). The economic historian Agnes M. Wergeland published a three-part study of slavery in medieval Germany in the Journal of Political Economy from 1900 to 1902, and published other articles there in each of the next three years.

Hannah Robie Sewall received her Ph.D. at the University of Minnesota in 1898 at the age of thirty-seven and taught there as an Assistant in Political Science from 1892 to 1902 (economics being part of the Department of Political Science). Her dissertation, The Theory of Value Before Adam Smith, was published in 1901 both in the Publications of the American Economic Association and by Macmillan. It was reprinted in 1968 and 1971 in Augustus M. Kelley's Reprints of Economic Classics. In 1985, Mark Blaug described it as "still the standard reference work on the subject" (quoted by Claire Holton Hammond in her entry on Sewall in Dimand, Dimand, and Forget, in preparation). Her subsequent report as special agent of the US Bureau of Labor to investigate child labor (Sewall 1904) collected data from 215 businesses in thirteen states on demographic, wage, and employment conditions of working children. The only available information about her career after 1904 is that in 1914, when she was fifty-three, Women's Who's Who described her as an economist, a member of the Just Government League of Maryland and of the National Child Labor Committee, with keeping bees listed as her main activity. She married a University of California geneticist some time after 1914, and died in 1926.

Katharine Coman graduated from the University of Michigan as a Bachelor of Pharmacy and then became instructor of rhetoric at the newly established Wellesley College. There, she became professor of political economy in 1883 and organised the department of economics and sociology, which she chaired until her death in 1915. She was succeeded by Emily Greene Balch. She published in the second volume of the Journal of Political Economy (Coman 1893) and a monograph in the Publications of the American Economic Association (Coman 1903). She wrote the first article in the American Economic Review (Coman 1911a), with another paper in the American Economic Review Supplement a month later (Coman 1911b). As an economic historian, Coman wrote on Economic Beginnings of the Far West ([1912] 1969), reissued in Kelley's Reprints of Economic Classics, and Industrial History of the United States (1917).

William Darity, in his introduction to the 1995 reprint of her 1904 article, "The Negro as Peasant Farmer," reports that: 
Coman's paper, while sharing most of the ideological presumptions of the rest of the economics profession about the competency of "the Negro", represented two major departures ... an analytical style that was far more sophisticated than other economists writing on the race question at that time ... a substantive awareness of the principal-agent problem and the selection bias problem ... the now familiar, but then fresh, claim that discriminatory differentials could not persist among equally efficient groups of workers ... After investigating the performance of blacks under different economic arrangements, she concluded that optimal black efficiency will be attained when blacks are converted into peasant proprietors, echoing John Stuart Mill's solution for the rural landless English (Coman 1904/1995).

While ill with cancer, Coman toured Europe for a study of unemployment insurance systems. This study appeared as a series of six articles in the American Association for Labor Legislation's Survey (plus an exchange with Ira Rubinow in another issue), and then posthumously, as a book (Coman 1915).

In addition to Coman (1903) and Sewall (1901), the Publications of the American Economic Association included an essay on child labor by Clare de Graffenreid (1890) and a monograph on public assistance to the poor in France by Emily Greene Balch (1893). Balch shared the Nobel Peace Prize in 1946 for the pacifist and social reform activism for which she lost her full professorship at Wellesley College in 1918 after twenty-four years teaching there. Like Coman (1904), Lucy M. Salmon (1892), Isabel Eaton (1895), and Alice Rhinehart Callaway (1898), were published by the American Statistical Association (cf. Salmon 1897). The Quarterly Journal of Economics did not carry nearly as many articles by women as did the Journal of Political Economy or the Economic Journal but, in addition to Collet (1891a), it published Alice Rollins Brewster (1894) on "Early Experiments with the Unemployed."

\section{WOMEN IN THE AUSTRALIAN ECONOMIST AND THE BRITISH EMPIRE}

The Australian Economist was published from 1888 to 1898 by the Australian Economic Association, founded in 1887, before the British Economic Association (now the Royal Economic Society) and inspired by the founding two years before of the American Economic Association. Miss Louisa MacDonald, M. A. (London, classics), Principal of the Women's College at the University of Sydney, published in The Australian Economist on "The Economic Position of Women" (1893). Miss Edith A. Barham, Headmistress of the Sydney Church of England Girls Grammar School, wrote skeptically on "Women and Womanhood Suffrage" (1895) and "Private and Public School Systems Compared" (1896). Miss Rose Scott, "'mother' of women's suffrage in Australia and founder of the first Tailoresses' Union" (Butlin, Fitzgerald, and Scott 1986, p. xiii), also contributed (Scott 1894) and commented on Badham (1895). The Australian Dictionary of Biography includes biographies of these three women.

The freelance journalist Florence Gordon (1894) marshalled an impressive body of empirical evidence on the low wages of women workers in Sydney. Margaret Hodge (1898) wrote about technical education in Germany. Previously, 
in December 1890, the Australian Economist had reprinted an article from the London Economist on "Working Women in the United States," reviewing the same material reviewed by Clara Collet (1891c). For a couple of years from July 1889, monthly meetings of the Association's Reading Circle worked through Alfred Marshall's and Mary Paley Marshall's Economics of Industry (1879), according to S. J. Butlin (in N. G. Butlin, Fitzgerald, and Scott 1986, p. xxiii). The Association's executive committee elected in December 1893 included Louisa MacDonald, Miss S. Hynes, BA, and Mrs. Haigh, together with three men (plus another seven men holding such positions as president, vicepresident, and honorary treasurer). MacDonald, Hynes, and Florence Gordon were on the executive committee elected in December 1894. Badham, Hynes, and Miss McKenny, who had published comments on Badham (1895 and 1896), were on that committee elected in December 1895. Edith Badham became a vice-president in December 1896, with Miss Tilley, who had published comments on Gordon (1894) and Badham (1895), joining Hynes and McKenny on the executive committee. Badham, Hynes, and McKenny were re-elected in 1897 and 1898, after which the Association dissolved. Few if any later national economic associations achieved such a level of female representation on their executives.

Elsewhere in the British Empire, Jean Thompson Scott published a thirty-one page study of The Conditions of Female Labour in Ontario (Scott 1892) in the Toronto University Studies in Political Science (First Series, No. III), edited by the economic historian W. J. Ashley, the founder of the Department of Political Economy at the University of Toronto. This notable Canadian publication appears to have been a more isolated occurrence than the activity of women in economics in Sydney, but Acton, Goldsmith, and Shepard (1974) cite Women Workers of Canada. Being a Report of the Proceedings of the First Annual Meeting and Conference of the National Council of Women, April 1894, and Helen R. Y. Reid's The Problem of the Unemployed, published by the National Council of Women some time in the 1890s. Annie Marion McLean, who wrote about "Factory Legislation for Women in Canada" in the American Journal of Sociology (McLean 1899), pursued a career as a sociologist in the United States.

Women were not prominent in the Economic Society of Australia and New Zealand (founded in 1925) and its journal, The Economic Record, founded the same year. However, the second volume of The Economic Record did include an article by a male economist on "The Employment of Married Women" (R. M. Campbell 1926). One who might have become prominent did not stay in Australia: Persia Crawford Campbell took her AB and AM at the University of Sydney before going on fellowship for two years at the London School of Economics (publishing her MSc thesis in 1923 as her first book, on Chinese Coolie Emigration to Countries in the British Empire) and one year as British Fellow at Bryn Mawr. She returned to Australia from 1924 to 1930 as an assistant editor of the Australian Encyclopedia and then as a research economist at the Industrial Commission of New South Wales (a wage-fixing tribunal). A two-year fellowship to Harvard (leading in 1933 to another book, American Agricultural Policy) was followed by a career of consumer advocacy in the United States and teaching at Queens College of the City University of New 
York where she became a full professor and department head. Her Columbia doctoral dissertation became her third book.

In contrast to the disappearance of women from Australian economics after substantial participation in the 1890s, the South African Journal of Economics carried two articles by Hansi P. Pollak in its first volume in 1933, the first on "Women workers in Witswatersrand industries," and opened its 1936 volume with a forty-two page article by her. The Journal published another paper by her in 1940, as well as articles by Sheila T. van der Horst of the University of Cape Town in 1934, 1935, 1939, 1941 (plus a reply to a comment), 1944, 1946, 1948 (plus a review article), 1951, 1954 (on "Equal pay for equal work"), 1956, and 1957. Dr. van der Horst also wrote a book on Native Labour in South Africa (1942), described by Harrison Wright (1977, p. 34) as a "fresh and interdisciplinary analysis," and she was a liberal critic of the post-1948 Nationalist apartheid regime (Hutt 1964, p. 140n; Wright 1977, p. 6; cf. Van der Horst 1965).

\section{CONCLUSION}

In addition to the outstanding figures of Charlotte Perkins Gilman and Rosa Luxemburg, a substantial number of women contributed to economics in the 1890s, including such significant scholars and activists as Emily Greene Balch, Helen Dendy Bosanquet, Helen Campbell, Clara Collet, Katharine Coman, Barbara Hammond, Bessie Leigh Hutchins, and Beatrice Webb, notwithstanding the sharply limited academic prospects for women at the time. They published in books, in the leading and more peripheral journals, and in Palgrave's Dictionary of Political Economy, where women were proportionately better represented than among the contributors to The New Palgrave ninety years later. Indeed, in the one-volume anthology of one hundred selected New Palgrave articles, the number of articles by women, four, is the same as the number by one man, Donald McCloskey.

Such participation extended beyond the metropolitan centers to the then peripheral scholarly communities in Sydney and Toronto. The participation of women in economics is by no means an exclusively recent phenomenon. The women who wrote on economic issues in the 1890 s devoted a higher proportion of their attention to labor markets, social issues, and economic history than the economics profession does now, but that was also true of male political economists of the $1890 \mathrm{~s}$. What was distinctive about their contribution was that such authors as Gilman (1898a, 1898b), Campbell (1887, 1893), and Fawcett $(1892,1918)$ analysed gender relations, women's poverty, and the wage gap between men and women, topics examined by only a few male economists, such as William Smart (1892). A century after both Gilman's Women and Economics and Rosa Luxemburg's dissertation, this rich heritage awaits rediscovery.

\section{REFERENCES}

Acton, Janice, Penny Goldsmith, and Bonnie Shepard, eds. 1974. Women at Work: Ontario 1850-1930. Toronto: Women's Press. 
Anderson, Adelaide M. 1895. "Joint Associations of Employers and Employed in France and Belgium," Economic Journal 5 (December): 641-50.

Badham, Edith A. 1895. "Women and Womanhood Suffrage." The Australian Economist 4 (14): 479-84, with discussion by Rose Scott, 4 (15): 492-94, and by Rose Scott, Rev. Dr. Bevan, Miss McKenny, Miss Tilley and others, 4 (16): 495-502.

- 1896. "Private and Public Schools Compared." The Australian Economist 4 (30): 607-10, with discussion by Prof. W. Scott and Miss Tilley, 4 (31): 619-22, discussion by Miss McKenny and a reply by Badham, 1897, 5 (1): 2-6.

Balch, Emily Greene. 1893. "Public Assistance of the Poor in France." Publications of the American Economic Association, First Series 8 (4-5): 1-180.

Barton, Dorothea M. 1919. "The Course of Women's Wages." Journal of the Royal Statistical Society 82 (July): 508-44.

- 1921. "Women's Minimum Wages." Journal of the Royal Statistical Society 84 (July): . 528-67.

Baumol, William J. 1985. "On Method in U. S. Economics a Century Earlier." American Economic Review 75 (December): 1-12.

Beilharz, Peter and Chris Nyland. 1998. The Webbs, Fabianism and Feminism. Aldershot, UK, and Brookfield, VT: Ashgate.

Berg, Maxine. 1992. "The First Women Economic Historians." Economic History Review 45 (May): 308-29.

Besant, Annie. 1889. "Industry Under Socialism." In George Bernard Shaw, ed., Fabian Essays on Socialism. Reprinted Garden City, NY: Doubleday, no date: 187-209.

B Tack, Anne and Barbara Bradby. 1899. "Women Compositors and the Factory Acts." Economic Journal 9 (June): 261-66.

Black, Clementina. 1904. "London's Tailoresses." Economic Journal 14 (December): 555-67.

Bliss, H. (Helen) L. 1895. "The Use and Value of Census Statistics." Journal of Political Economy 4 (December): 86-93.

- 1897. "Some Oddities of Statistical Method." Journal of Political Economy 6 (December): $100-14$.

- 1898. "Census Statistics of Unemployment." Journal of Political Economy 6 (March): $250-53$.

- 1899. "An Error in the Use of Statistics of Population." Journal of Political Economy 8 (December): 94-98.

- 1901. "New York Labor Statistics." Journal of Political Economy 9 (March): 272-82.

- 1905. "Census Statistics of Child Labor." Journal of Political Economy 13 (March): 245-57.

Bondfield, Margaret G. 1899. "Conditions Under Which Shop Assistants Work." Economic Journal 9 (June): 277-286.

- 1928. "The Meaning of Trade." In Self and Society, First Twelve Essays: Social and Economic Problems from the Neglected Point of View of the Consumer. London: Ernest Benn.

Booth, Charles, ed. 1902. Life and Labour of the People in London. London: Macmillan. 1970.

Bosanquet, Helen Dendy. 1891. "The Causes of Poverty." Economic Journal 1 (December): 808-10.

- 1893. "The Industrial Residuum." Economic Journal 3 (December): 600-16.

—. 1896. "The Burden of Small Debts." Economic Journal 6 (June): 212-25.

—. 1897. "The Lines of Industrial Conflict." Economic Journal 7 (December): 503-10.

Brewster, Alice Rollins. 1894. "Early Experiments with the Unemployed." Quarterly Journal of Economics 9 (October): 88-95.

Bryant, Sophie Willock. 1894. "Educational Finance." Economic Journal 4 (March): 94-105.

Butlin, F. M. 1899. "International Congress of Women." Economic Journal 9 (September): $450-55$.

Butlin, Noel G., V. W. Fitzgerald, and R. H. Scott, eds. 1986. The Australian Economist 1888-1898, 2 volumes, facsimile ed. Sydney: Australian National University Press.

Callaway, Alice Rhinehart. 1898. "The Workman in Berlin." Quarterly Publications of the American Statistical Association 6 (June): 102-06.

Campbell, Helen. 1887. Prisoners of Poverty: Women Wage Workers, Their Trades and Their Lives. Boston: Roberts Brothers, reprinted Greenwood Press, Westport, CT, 1970. 
1 1893. Women Wage-Earners: Their Past, Their Present and Their Future, with an introduction by Richard T. Ely. Boston: Roberts Brothers.

. 1896. Household Economics. New York: G. P. Putnam's Sons.

Campbell, R. M. 1926. "The Employment of Married Women." Economic Record 2 (November): 271-75.

Collet, Clara Elizabeth. 1891a. "Wages and the Standard of Living." Quarterly Journal of Economics 5 (April): 365-68.

- 1891b. "Reports of the Massachusetts Bureau of Statistics of Labor on Working Women, 1870-1889." Economic Journal 1 (June): 398-405.

—. 1891c. "Women's Work in Leeds." Economic Journal 1 (September): 460-73.

- 1898a. "The Collection and Utilisation of Official Statistics Bearing on the Extent and Effects of the Industrial Employment of Women." Journal of the Royal Statistical Society 61 (June): $219-60$.

- 1898b. "The Expenditure of Middle Class Working Women." Economic Joumal 8 (December): 543-53.

Coman, Katharine. 1893. "Wages and Prices in England, 1261-1701." Journal of Political Economy 2 (December): 92-94.

- 1903. "History of Contract Labor in the Hawaiian Islands." Publications of the American Economic Association, Third Series, 4 (3): 1-74.

—. 1904. "The Negro as Peasant Farmer." Quarterly Publications of the American Statistical Association 9 (June): 39-54. Reprinted in William A. Darity, Jr., ed., Economics and Discrimination, Volume I. Aldershot, UK, and Brookfield, VT: Edward Elgar, 1995.

- 191 la. "Some Unsettled Problems of Irrigation." American Economic Review 1 (March): $1-19$.

—. 1911b. "Government Factories: An Attempt to Control Competition in the Fur Trade." American Economic Review Supplement 1 (April): 368-88.

- 1912. Economic Beginnings of the Far West. New York: Macmillan. Reprinted New York: A. M. Kelley, 1969.

- 1915. Unemployment Insurance: A Summary of European Systems. New York: Progressive National Service.

- 1917. Industrial History of the United States. New York: Macmillan.

Cunningham, William and Ellen McArthur. 1895. Outlines of English Industrial History, London: Macmillan; $4^{\text {th }}$ ed., Cambridge, UK: Cambridge University Press, 1928.

Davenport, Frances Gardiner. 1897. "The Agricultural Changes in the Fifteenth Century." Quarterly Journal of Economics 11 (January): 205-210.

Davenport-Hill, Florence. 1893. "The System of Boarding-Out Pauper Children." Economic Journal 3 (March): 62-73.

Davis, Katharine Bement. 1898. "Tables Relating to the Price of Wheat and Other Farm Products Since 1890." Journal of Political Economy 6 (June): 403-10.

- 1899. "An Error in Austrian Wage Statistics." Journal of Political Economy 8 (December): $102-06$.

—. 1900a. "The Condition of the Negro in Philadelphia." Journal of Political Economy 8 (March): 248-60.

- 1900b. "The Modern Condition of Agricultural Labor in Bohemia." Journal of Political Economy 8 (September): 491-523.

- 1929. Factors in the Sex Life of Twenty-Two Hundred Women. New York: Harper and Brothers. Reprinted Arno Press: New York, 1972.

Deverell, Edith. 1898. "Shop Benefit Clubs." Economic Journal 8 (January): 243-54.

- 1899. "Slate Clubs." Economic Journal 9 (June): 266-77.

Dietrich, Ethel B. 1928. "The Plight of the Lancashire Cotton Industry." American Economic Review 18 (September): 468-76.

Dimand, Mary Ann. 1995a. "Networks of Women Economists Before 1940." In Mary Ann Dimand, Robert W. Dimand, and Evelyn L. Forget, eds., Women of Value: Feminist Essays on the History of Women in Economics. Aldershot: Edward Elgar, 39-59.

—. 1995b. "The Economics of Charlotte Perkins Gilman." In Mary Ann Dimand, Robert W. Dimand, and Evelyn L. Forget, eds., Women of Value: Feminist Essays on the History of Women in Economics. Aldershot: Edward Elgar, 124-49. 
Dimand, Mary Ann, Robert W. Dimand, and Evelyn L. Forget, eds. 1995. Women of Value: Feminist Essays on the History of Women in Economics. Aldershot: Edward Elgar.

Dimand, Robert W. 1995. "The Neglect of Women's Contributions to Economics." In Mary Ann Dimand, Robert W. Dimand, and Evelyn L. Forget, eds., Women of Value: Feminist Essays on the History of Women in Economics. Aldershot: Edward Elgar, 1-24.

- 1998. "Women in the Canon of Economics." Presented to "Reflecting on the Canon: A Conference in Honour of Sam Hollander." Toronto, September.

Dimand, Robert W., Mary Ann Dimand, and Evelyn L. Forget, eds. In preparation. Biographical Dictionary of Women Economists. Edward Elgar, Cheltenham, UK, and Lyme, NH.

Dixon, E. 1895. "Craftswomen in the Livre des métiers." Economic Journal 5 (June): 209-28.

Douglas, Dorothy Wolff. 1920. "The Cost of Living for Working Women: A Criticism of Current Theories." Quarterly Journal of Economics 34 (February): 225-59.

. 1940. "Land and Labor in Mexico." Science and Society 4 (2): 127-52.

- 1953. Transitional Economic Systems: The Polish-Czech Example. London: Routledge \& Kegan Paul.

Douglas, Paul and Dorothy Wolff Douglas. 1921. "What Can a Man Afford?" American Economic Review Supplement 11 (March): 1-95. Also in What Can a Man Afford? Two Essays Awarded the Karelsen Prizes by the American Economic Association. Princeton NJ, and New Haven, CT: American Economic Association.

Eaton, Isabel. 1895. "Receipts and Expenditures of Certain Wage-Earners in the Garment Trades." Quarterly Publications of the American Statistical Association 4 (June): 135-80.

Eatwell, John, Murray Milgate, and Peter Newman, eds. 1987. The New Palgrave: A Dictionary of Economics, 4 volumes. London: Stockton Press.

Fawcett, Henry and Millicent G. Fawcett. 1872. Essays and Lectures on Social and Political Subjects. London: Macmillan.

Fawcett, Millicent G. 1870. Political Economy for Beginners. London and Cambridge: Macmillan.

- 1874. Tales for Political Economy. London: Macmillan.

—. "Mr. Sidney Webb's Article on Women's Wages." Economic Journal 2 (March): 173-76. . 1918. "Equal Pay for Equal Work." Economic Journal 28 (March): 1-6. Reprinted in William A. Darity, Jr., ed., Economics and Discrimination, Volume 1. Aldershot: Edward Elgar, 1995.

Felton, Katharine. 1898. "Rousiers's Theory of the Evolution of the Laborer." Journal of Political Economy 6 (June): 380-95.

Fisher, Lettice. 1899. "Labourers's Dwellings.” Economic Journal 9 (December): 605-11.

- 1902. "Local Authorities and the Housing Problem in 1901." Economic Journal 12 (June): 263-71.

- 1905. "The Town Housing Problem." Economic Journal 15 (March): 23-26.

Foley, Caroline A. 1893. "Fashion." Economic Journal 3 (September): 458-74.

Fullbrook, Edward. 1998. "Caroline Foley and the Theory of Intersubjective Demand." Journal of Economic Issues 32 (Fall): 709-31.

Gilman, Charlotte Perkins. 1898a. Women and Economics: The Economic Factor Between Men and Women as a Factor in Social Evolution. Boston: Small, Maynard. Reprinted with an introduction by Carl N. Degler, New York: Harper Torchbooks, 1966; reprinted Amherst, NY: Prometheus Books, 1994.

—. 1898b. "Economic Basis of the Woman Question." Woman's Journal 1 (October). Partially reprinted in Aileen Kraditor, ed., Up From the Pedestal: Landmark Writings in the American Woman's Struggle for Equality. Chicago: Quadrangle Books, 1968.

- 1903. The Home: Its Work and Influence. Reprinted New York: New York Source Books, 1970.

Gordon, Florence. 1894. "The Condition of Female Labour and the Rates of Women's Wages in Sydney." The Australian Economist 4 (7): 423-29, and "Women's Work and Wages: Reply." The Australian Economist, 4 (10): 454, and 4 (11): 459-60, with discussion by W. McMillan, 4 (7) 429-30, by Miss Tilley, 4 (8): 437-38, and general discussion, 4 (9): 444-46.

Graffenreid, Clare de. 1890. "Child-Labor." In W. F. Willoughby and Clare de Graffenreid, "Two Essays on Child-Labor." Publications of the American Economic Association, First Series 5 (2). 
Groenewegen, Peter D., ed. 1994. Feminism and Political Economy in Victorian England. Aldershot: Edward Elgar.

Groenewegen, Peter D. and Susan King. 1994. "Women as Producers of Economic Articles: A Statistical Assessment of the Nature and Extent of Female Participation in Five British and North American Journals 1900-1939." University of Sydney Working Papers in Economics no. 201 .

Hammond, J. L. and Barbara Hammond. 1911. The Village Labourer, 1760-1832. London: Longmans, Green.

- 1917. The Town Labourer, 1760-1832. London: Longmans, Green. 1919. The Skilled Labourer, 1760-1832. London: Longmans, Green.

Hardy, S. (Sara) McLean. 1895. "The Quantity of Money and Prices, 1860-1891: An Inductive Study." Journal of Political Economy 3 (March): 145-68.

Hazard, Blanche E. 1913. "The Organization of the Boot and Shoe Industry in Massachusetts Before 1875." Quarterly Journal of Economics 27 (February): 236-62.

Heather-Bigg, Ada. 1894. "The Wife's Contribution to Family Income." Economic Journal 4 (March): 51-58.

Hewart, Beatrice. 1898. "The Wages of London Vestry Employees." Economic Journal 8 (September): 407-14.

- 1900. "The Cloth Trade in the North of England in the Sixteenth and Seventeenth Centuries." Economic Journal 10 (March): 20-31.

Hill, Caroline M. 1904. "The Economic Value of the Home." Journal of Political Economy 12 (June): 408-19.

Hill, Mary A. 1980. Charlotte Perkins Gilman: The Making of a Radical Feminist, 1860-1896. Philadelphia: Temple University Press.

Hodge, Margaret. 1898. "Technical Education in Germany." The Australian Economist 6 (4): 25-29.

Hogarth, Janet E. 1896. "The German Insurance Laws." Economic Journal 6 (June): 283-94.

Howe, Florence. 1989. "Practical in Her Theories: Theresa McMahon, 1878-1961." In Geraldine Jonçich Clifford, ed., Lone Voyagers: Academic Women in Coeducational Institutions, 1870-1937. New York: The Feminist Press at the City University of New York, 223-80.

Hutchins, Bessie Leigh. 1899-1900. "Notes Towards the History of London Wages." Economic Journal 9 (December): 599-605, and 10 (March): 103-04.

- 1915. Women in Modern Industry. London: G. Bell \& Sons.

Hutchins, Bessie Leigh and A. Harrison. 1903. A History of Factory Legislation. London: P. S. King \& Son, $3^{\text {rd }}$ ed. 1926.

Hutt, W. H. 1964. The Economics of the Colour Bar. London: Andre Deutsch.

Jastrow, Henriette. 1899. "Domestic Servants in Germany: Their Economic, Social and Legal Position." Economic Journal 9 (December): 625-33.

Jayawardena, Kumari. 1995. The White Woman's Other Burden: Western Women and South Asia During British Colonial Rule. London and New York: Routledge.

Knowles, Lillian C. A. 1921. The Industrial and Commercial Revolutions in Great Britain During the Nineteenth Century. London: George Routledge \& Sons, $7^{\text {th }}$ ed. 1930.

- 1924. The Economic Development of the British Overseas Empire, 1763-1914. London: George Routledge \& Sons (Volume II, with C. M. Knowles, 1930).

Knowles, Lillian C. A. 1932. Economic Development in the Nineteenth Century: France, Germany, Russia and the United States. London: George Routledge \& Sons.

Kyrk, Hazel. 1923. A Theory of Consumption. Cambridge, MA: Houghton Miffin, The Riverside Press.

1933. Economic Problems of the Family. New York: Harper \& Brothers.

Levetus, Amelia Sarah. 1897. "Working Women in Vienna." Economic Journal 7 (March): 101-09.

Luxemburg, Rosa. 1898. The Industrial Development of Poland. Leipzig. Trans. Tessa DeCarlo with introduction by Lyndon H. LaRouche, Jr. New York: Campaigner Publications, 1977.

- 1913. The Accumulation of Capital. Trans. Agnes Schwarzschild with introduction by Joan Robinson. London: Routledge, and New Haven, CT: Yale University Press, 1951.

MacDonald, Louisa. 1893. "The Economic Position of Women." The Australian Economist 3 (11): 367-72, with discussion by Professor Scott, Hon. L. F. Heydon, Mr. Duckworth, and J. Hurst, Jr., 4 (1): 375-81. 
Malveaux, Julianne. 1991. "Missed Opportunity: Sadie Tanner Mossell Alexander and the Economics Profession." American Economic Review 81 (May) 307-10. Reprinted in Thomas D. Boston, ed., A Different Vision, Volume 1: African American Economic Thought. London and New York: Routledge, 1997.

Marshall, Alfred and Mary Paley Marshall. 1879. Economics of Industry. London: Macmillan. Reprinted with introduction by D. P. O'Brien, Bristol: Thoemmes Press, 1994.

Marshall, Mary Paley. 1896. "Notes and Memoranda: Conference of Women Workers." Economic Journal 6 (March): 107-09. 1902. "Educated Working Women by Clara E. Collet." Economic Journal 12: 252-57.

McBriar, A. M. 1987. An Edwardian Mixed Double: The Bosanquets versus the Webbs. Oxford: Clarendon Press.

McMahon, Theresa Schmid. 1912. Women and Economic Evolution. Madison, WI: University of Wisconsin Bulletin No. 496.

McLean, Annie Marion. 1899. "Factory Legislation for Women in Canada." American Journal of Sociology 5(2): 172-81.

Meade, Emily Fogg. 1901. "The Place of Advertising in Modern Business." Journal of Political Economy 9 (March): 218-42.

Meyer, Annie, ed. 1891. Women's Work in America. New York: Henry Holt.

Orchard, Dorothy Johnson. 1929. "Agrarian Problems of Modern Japan, Parts I and II." Journal of Political Economy 37 (April): 129-49, and (June): 285-311.

Osborn, Christabel. 1895a. "The Slums of Great Cities." Economic Journal 5 (September): 474-76.

- 1895b. "Review: Trade Depression in Maine, USA." Economic Journal 5 (September): 476-77.

—. 1898. "Railway Brotherhoods in the United States." Economic Journal 8 (December): 577-79.

Palgrave, R. H. I., ed. 1894-99. Dictionary of Political Economy, 3 vols. London: Macmillan, 1910.

Polkinghorn, Bette A. and Dorothy Lampen Thompson. 1998. Adam Smith's Daughters: Eight Prominent Women Economists from the Eighteenth Century to the Present. Cheltenham, UK, and Northampton, MA: Edward Elgar.

Potter, Beatrice. 1891. The Co-operative Movement in Great Britain. London: Swann Sonnenschein.

Pujol, Michèle. 1992. Feminism and Anti-Feminism in Early Economic Thought. Aldershot: Edward Elgar. Reprinted with introduction by Janet A. Seiz, 1998.

Salmon, Lucy Maynard. 1892. "A Statistical Inquiry Concerning Domestic Service." Quarterly Publications of the American Statistical Association 3 (June-September): 89-118.

Salmon, Lucy Maynard. 1897. Domestic Service. New York: Macmillan.

Scott, Jean Thompson. 1892. "The Conditions of Female Labour in Ontario." Toronto University Studies in Political Science, First Series, No. III.

Scott, Rose. 1894. "Remarks on Presidential Address." The Australian Economist 4 (6): 421-22.

Sewall, Hannah Robie. 1901. "The Theory of Value Before Adam Smith." Publications of the American Economic Association, Third Series, 2:3, 1-132, and New York: Macmillan. Reprinted New York: Augustus M. Kelley, 1968 and 1971.

1904. "Child Labor in the US." US Bureau of Labor Bulletin 52 (May): 485-637.

Shapiro, Laura. 1986. Perfection Salad: Women and Cooking at the Turn of the Century. New York: Henry Holt.

Sinclair, Andrew. 1965. The Emancipation of the American Woman. New York: Harper \& Row.

Smart, William. 1892. "Women's Wages." Proceedings of the Philosophical Society of Glasgow 23: $87-105$.

Sumner, Helen. 1910. History of Women in Industry in the United States, US Senate Report on Condition of Woman and Child Wage-Earners in the United States, Volume IX (Doc. No. $645,61^{\text {st }}$ Congress, $2^{\text {nd }}$ session), Washington, DC.

Van der Horst, Sheila T. 1942. Native Labour in South Africa. Oxford: Oxford University Press. 1965. "The Effects of Industrialisation on Race Relations in South Africa." In Guy Hunter, ed., Industrialisation and Race Relations: A Symposium. London. 
Van der Veen, Margrieta. 1898a. "Homework in Berlin." Economic Journal 8 (March): 143-46.

- 1898b. "The Conference on Women's Work at the Hague." Economic Journal 8 (September): 404-07.

Veblen, Thorstein. 1899. The Theory of the Leisure Class. New York: Penguin, 1979.

Ware, Caroline F. 1926. "The Effect of the American Embargo, 1807-1809, on the New England Cotton Industry." Quarterly Journal of Economics 40 (August): 673-88.

Ware, Caroline F. 1931. The Early New England Cotton Manufacture. Boston: Houghton Mifflin. Reprinted New York: Russell \& Russell, 1966.

—., ed. 1940. The Cultural Approach to History. New York: Columbia University Press.

Webb, Beatrice. 1896. Women and the Factory Acts, Fabian Tract No. 67. London: Fabian Society.

Webb, Sidney and Beatrice Webb. 1894. The History of Trade Unionism. London: Longmans.

- 1896a. "The Method of Collective Bargaining." Economic Journal 6 (March): 1-29.

- 1896b. "The Standard Rate." Economic Journal 6 (September): 356-88.

- 1897. Industrial Democracy. London: Longmans.

- 1903/1930. History of English Local Government, 1688-1835, 11 volumes, with additional essays by B. Keith-Lucas, G. J. Ponsonby, L. Radzinowicz, and W. A. Robson. London: Frank Cass, 1963.

Wergeland, Agnes M. 1900-1902. "Slavery in Germanic Society During the Middle Ages, Parts I-III." Journal of Political Economy 9 (December 1900): 98-120; 9 (June 1901): 398-422; 1 (March 1902): 230-54.

Wright, Harrison. 1977. The Burden of the Present: Liberal-Radical Controversy Over Southern African History. Cape Town: David Philip. 